\title{
Serological Study of African Swine Fever in Traditional Pig Farms in Chad
}

\author{
Bidjeh Kebkiba ${ }^{1}$, ", Ban-Bo Bebanto Antipas², Nadjilem Digamtar², Tchari Doungous ${ }^{1}$, \\ Golwa Dinza ${ }^{2}$, Maho Adnelie jeanne ${ }^{2}$ \\ ${ }^{1}$ Livestock Research Institute for Development, Ndjamena, Chad \\ ${ }^{2}$ Faculty of Exact and Applied Sciences (FEAS), University of Ndjamena, Ndjamena, Chad
}

\section{Email address:}

Bidjehkebkiba@yahoo.fr (B. Kebkiba)

\section{To cite this article:}

Bidjeh Kebkiba, Ban-Bo Bebanto Antipas, Nadjilem Digamtar, Tchari Doungous, Golwa Dinza, Maho Adnelie jeanne. Serological Study of African Swine Fever in Traditional Pig Farms in Chad. Animal and Veterinary Sciences. Vol. 3, No. 6, 2015, pp. 149-152.

doi: $10.11648 /$ j.avs.20150306.11

\begin{abstract}
African swine fever (ASF) is an acute, highly contagious animal disease, affecting pigs and wild boars, warthogs, bush pigs and ticks (Ornithodoros), who are the likely vector. Its agent is a large double-stranded DNA virus of the genus Asfarvirus, the only representative of Asfarviridae family. Described for the first time in 1921 in East Africa (Kenya) by Montgomery, ASF has settled in the Iberian Peninsula. Since 1960, ASF has spread considerably in sub-Saharan Africa where it is endemic. ASF has emerged in Chad for the first time in October 2010 in the city of Bongor, capital of the region of MayoKebbi-East, which is located about $250 \mathrm{~km}$ from Ndjamena. The city borders with northern Cameroon where the disease was reported in May 2010. The disease was introduced into the country from the far north in the Department of Mayo Danaye, Cameroon. Since 2010-2011, suspicions have become rare or no observed. The purpose of this study is to demonstrate the presence or absence of ASF virus circulation in Chad in order to clarify the epidemiological situation of the disease in the country. To do this, a serological survey was conducted on different sites. The choice of these sites was based on the history of the disease in the country, where there has actually outbreaks of disease and on stamping out importance achieved during ASF episode of 2010-2011. A total of 275 Sera and 17 bloods on filter papers were collected and analyzed by indirect ELISA for antibodies directed to ASF virus. Out of 275 sera analyzed, $13(4.72 \%)$ have had antibodies directed to ASF virus. No sample taken from filter papers was positive vis-à-vis ASF virus. The study identified 4.72\% animals carrying ASF virus. Given these results, we can say that ASF virus still circulates in some areas of the country. The areas where sera were positive should be admitted to the extent control of ASF by implementing the strategy of stamping out.It would also be preferable to undertake another large-scale serological study coupled with active surveillance to show that indeed there is no circulation of ASF virus in the country.
\end{abstract}

Keywords: Pigs, ELISA, Serology, African Swine Fever, Antibodies, Viruses, Serum

\section{Introduction}

African swine fever is a viral disease highly contagious hemorrhagic that affects pigs, warthogs, wild boars $[1,6]$ and Ornithodoros ticks, which are the likely vector [14]. It was described for the first time in 1921 in Kenya, East Africa, and few years after in South Africa and Angola Montgomery [12]. All the age groups are also susceptible to the disease [11, 15]. Its agent is a large double-stranded DNA virus of the genus Asfarvirus [5]. This virus replicates in the cytoplasm of infected cells [10]. It is the only representative of the family Asfarviridae [5]. The disease expresses in her shrill and acute form hemorrhagic fever. The mortality rate is often close to $100 \%$ in pigs of all ages [6,15]. Since 1960, ASF has gained considerable momentum in sub-Saharan Africa where it is endemic. The disease has been eradicated in South Africa in the 70s and 80s $[6,17]$. According to AU/IBAR and the World Organization for Animal Health (OIE) [2, 13], he latest outbreaks of ASF in West Africa have been recorded in Ivory Coast in 1996 and 2014; in Benin, Togo, Nigeria and Cape Verde in 1997 and 2001; in Ghana in 1999 and 2009; in Gambia in 2000. According to the same source, in Central Africa, the disease has been recorded in 
Chad in 2010, 2011 and 2014; in Cameroon in 2010 in Zambia in 2008, 2009, 2010 and 2012. It is often reported in Senegal and Guinea Bissau [8].

The episodes of the African swine fever were observed in several European countries (France, Spain, Portugal. ..), the countries of South America and the Caribbean (Cuba, Brazil and Haiti).But the disease has been eradicated [7, 9].

In Chad, as in many African countries, the pig is essentially in the hands of small operators, who practice a traditional way (free-living hosts) According to the Research, Statistics, Programming and archives, Department of Ministry of Livestock and Water, since 2010 pig population has experienced a death rate of nearly $60-80 \%$ due to African swine fever [18]. ASF has emerged in the country for the first time in October 2010 in the city of Bongor, capital of the region of Mayo-Kebbi-East, which is located about $250 \mathrm{~km}$ from Ndjamena. The city borders with northern Cameroon, where the disease was reported in May 2010. The disease was introduced into the country from the far north in the Department of Mayo Danaye, Cameroon [4, 18]. Despite all the measures taken by the Veterinary Authorities of Chad (Directorate of Veterinary Services), after five months, the disease was reported in Chad. And in less than four months, the disease has affected five regions namely Mayo-KebbiEast, Mayo-Kebbi-West, Tandjile, western Logone and Chari-Baguirmi [3, 4]. The Control strategy implemented to contain the outbreaks of the disease was stamping out. The application of these measures, the unusual practices and precarious socio-economic conditions of rural populations appear to accelerate the spread of the disease in the country [3]. Also, the application of stamping out prompted the producers of pigs to cross the already porous borders with their pets to avoid stamping out, as accompanying measures have not been followed by compensation $[3,4]$. The purpose of this study is to demonstrate the presence or absence of ASF virus circulation in Chad.

\section{Materials and Methods}

The sampling protocol results from purposive sampling taking into account the old infected sites, the other uninfected sites and border areas. The localities were therefore selected according to these various criteria and on the importance of stamping out performed during the episode of ASF in 20102011. These are the following veterinary posts: Ndjamena, Kelo, Bongor, Moulkou, Pala, Lai and Moundou(Figure 1). The number of samples by locality had been forecasted for 100 sera by locality, but due to budgetary constraints, this number could not be reached.

Blood is collected at the ear vein in dry tubes hen left at room temperature; after clots are detached from the tube wall and removed. The content of the tubes is then sent to the laboratory on ice for harvesting sera. In the laboratory, the tube contents are centrifuged at $3000 \mathrm{rpm} / \min$ for 15 minutes and then decanted. The resulting sera were stored at minus $20^{\circ} \mathrm{C}$ until further use. Apart from sera, blood is also collected on filter papers (filter paper, Whatman, ref. \#
Wb120210), then dried at room temperature and then sent to the laboratory for analysis. Analysis of elution of the filter papers was performed by the indirect ELISA test according to the protocol specified by the manufacturer. The ELISA kit used for this work is that marketed by $I D$ vet. It is prescribed by the World Organization for Animal Health (OIE) for the diagnosis of African swine fever. The said kit is based on three recombinant antigens $\mathrm{P}_{32}, \mathrm{P}_{62}$ and $\mathrm{P}_{72}$. It was provided by IRED. Other levies materials such as dry tubes, needles and tube holders were also provided by IRED. The work was carried out at the Serology Unit of Virology Department of the said Institute. A total of 275 serums were collected from different sites (Table 1). The study was funded by the University of Ndjamena (Chad).

\section{Results}

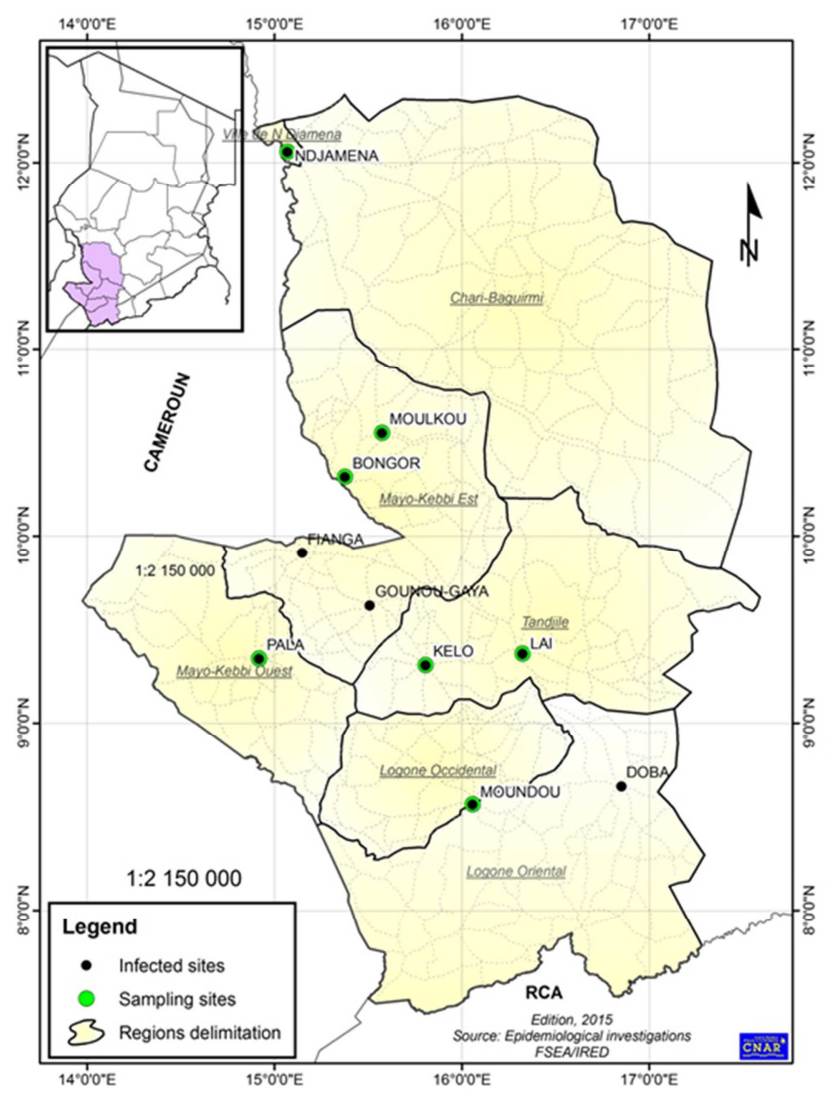

Fig. 1. Previously infected areas, infected and sampling sites.

The serology results are compiled in Table 1, from which one can notice that out of 275 serums analyzed only 13 $(4.72 \%)$ were positive vis-à-vis ASF virus. Sera collected in Moundou, Pala and Moulkou were negative. All 17 elution of blood from filter papers were negative Vis aVis African swine fever virus. From the same table one can see that the city of kelo has high seroprevalence of ASF virus (38. 9\%). The weak seroprevalence was obtained in Walia (3. 12\%). Analysis of positive sera shows that they were taken mainly from sows. Young pigs aged 0-10 months also show high seroprevalence rate $(46.15 \%)$. 
Table 1. Results of serology.

\begin{tabular}{lllllll}
\hline Sampling sites & $\begin{array}{l}\text { Total sera } \\
\text { collected }\end{array}$ & $\begin{array}{l}\text { Total sera } \\
\text { tested }\end{array}$ & Positive sera & $\begin{array}{l}\text { Compared to sera } \\
\text { tested }\end{array}$ & Doubtful sera & $\begin{array}{l}\text { compared to tested } \\
\text { sera }\end{array}$ \\
\hline Walia & 32 & 32 & 1 & $3.12 \%$ & 0 & $0 \%$ \\
& 21 & 21 & 8 & $38.9 \%$ & 1 & $4.76 \%$ \\
Moulkou & 20 & 20 & 0 & $0 \%$ & 0 & $0 \%$ \\
Bongor & 20 & 20 & 4 & $20 \%$ & 0 & $0 \%$ \\
Moundou & 104 & 104 & 0 & $0 \%$ & 0 & $0 \%$ \\
Pala & 78 & 78 & 0 & $0 \%$ & 1 & $1.28 \%$ \\
Grand Total & 275 & 275 & 13 & & & \\
\hline
\end{tabular}

\section{Discussion}

Since the episodes of 2010 and 2011, there were two suspected cases of ASF, which were reported by field staff: One in Ndjamena Walia neighborhood and the other in Bere (Tandjile) on both reported suspicions, only one (Walia) was confirmed by the laboratory (LANAVET in Cameroon by PCR. and IRED in Chad by the indirect ELISA test). The negative results obtained at Bere can be explained by the fact that maybe the samples were carried out on animals that would be at the beginning of the infection and might have not had time to develop antibodies against ASF virus or there is no circulation of ASF virus in this area.

Table 2. Distribution of positive sera by sampling sites, sex and age.

\begin{tabular}{llll}
\hline Reference & Sampling sites & Sex & Age (month) \\
\hline F4p1N & Ndjamena-Walia & NI & NI \\
F2P1K & Kelo & M & 10 \\
F3P1K & Kelo & M & 12 \\
F3P3K & Kelo & F & 8 \\
F4P2K & Kelo & M & 8 \\
F6P1K & Kelo & M & 7 \\
F7P1K & Kelo & F & 7 \\
F10P1K & Kelo & M & 12 \\
F11P1K & Kelo & F & 12 \\
F1P1B & Bongor & F & 48 \\
F3P1B & Bongor & F & 12 \\
F6P2B & Bongor & F & 36 \\
F7P1B & Bongor & F & 9 \\
\hline
\end{tabular}

Legend: $\mathrm{F}_{\mathrm{x}}=$ Farm number; $\mathrm{P}_{\mathrm{y}}=$ pig number; $\mathrm{N}=$ Ndjamena; $\mathrm{K}=$ Kelo; $\mathrm{B}=$ Bongor; $\mathrm{NI}=$ no information

The positive sera were likely taken from the animals, who have escaped stamping out because stamping out logging in these areas was not well adapted. However, one cannot attribute these positive results to a new outbreak of the disease since the producers say they have no evidence of clinical signs related to ASF in these areas previously infected with the virus. These results corroborate those described by Shlafer et al. (1984) [16] and Malogolovkin et al. (2015) [11], who reported that animals who survive remain carriers of the ASF virus lifetimes. The same sources explained that these animals really shed virus only during 5-6 weeks after infection. However, they may have a second clinical episode and become contagious again. Regarding the sites where sera were negative, given the proximity of outbreaks sites to them, socio-economic and cultural activities of producers could leave to suspect a new virus circulation in these sites. Thus, additional investigations seem therefore necessary to clarify the epidemiological situation of the disease in the area.

After the delineation of zones (infected, control or protected and surveillance zones), the measures applied in the control zone is by far the most effective and applied in countries in America, Europe and other countries in Africa. But the application of stamping out in the control zone, an unusual practice in Chad and the precarious socio-economic conditions of rural populations appeared to accelerate the spread of the disease in the country, indeed producers of pigs already crossed the porous border with their animals to escape stamping out because the accompanying measures forecasted in sanitary regulation document have not been followed by compensation. Also, ASF was confirmed in a warthog in the city of Ati located at $450 \mathrm{~km}$ from Ndjamena [3, 4].

High seroprevalence found in young pig populations demonstrated that the virus still circulates in some areas. This supported the fact that some pigs would escape the stamping out and still carried the virus, which infected young animal because they became again contagious.

\section{Conclusion}

The study identified $4.72 \%$ animals carrying ASF virus. Given these results, we can say that ASF virus still circulates in some areas of the country. The areas tested positive should be admitted to the extent control of ASF by stamping out. This should tart from the control or protected zone to go in the infected zone. It would also be preferable to undertake another large-scale serological study coupled with active surveillance to show that indeed there is no circulation of ASF virus in the country.

\section{Acknowledgments}

The authors thank sincerely the University of Ndjamena for kindly funding this study.

We express our deep gratitude to the General Directorate of Livestock Research Institute for Development for providing the kits and sampling materials.

Our Thanks go to national center for research support (CNAR) for kind designing the map. 
Our thanks also go to the field workers for their fine contribution to the collection of samples.

We thank all those who in one way or another, contributed to the realization of this study.

\section{References}

[1] E. C. ANDERSON, G. H. HUTCHING, N. MUKARATI, et al. African swine fever virus infection of the bushpig (Potamochoerus porcus) and its significance in the epidemiology of the disease. Vet. Microbiology, 1998, 62 (1), $1-15$

[2] AU-IBAR Joint AU-IBAR/ FAO African swine fever control strategy. 2013, 20p.

[3] B. A. BAN-BO, O. A. IDRISS, C. D. SQUARZONI Control of African Swine Fever (ASF) in traditional pig farms in Chad, Journal of Animal \& Plant Science, 2012, 15, 3, 22612266.

[4] B. A. BAN-BO, O. A. IDRISS, Alhaji Mahamat SOULEYMANE. Dynamics of African swine fever in Chad. Science and Technology, Natural Sciences and Agronomy, 2010-2012, 32, (1-2), 61-72.

[5] A. D. BASTOS, M. L. PENRITH, C CRUCIERE, J. L. EDRICH, G. H. HUTCHING, F. ROGER, et al. Genotyping field strains of African swine fever virus by partial p72 gene characterisation. Arch. Virol. 2003, 148, 693-706

[6] S. C. G. BLOME, C. GABRIEL, M. BEER. Pathogenesis of African swine fever in domestic pigs and European wild boar. Virus Res. 2013, 173:122-130.

[7] CONTINI, A., COSSU, P., RUTILI, D. et al. African swine fever in Sardinia. In: Wilkinson, P. J., African swine fever. Proceedings of CEC/FAO research seminar, Sassari, Sardinia, 23-25 sept. 1981. Brussels: Commission of the European Communities, 1982, 1-6.

[8] FAO (ML Penrith, et al.). Preparation of contingency plans against african swine fever, Rome, 2011, 84p.
[9] W. A. GEERING, M. L. PENRITH, D. NYAKAHUMA. Manual on the preparation of Africa swine fever contingency plans. Animal Health Manual. FAO, Rome. 2001, 11, 74p.

[10] T. LEWIS, L. ZSAK, T. G. BURRAGE, Z. LU, G. F. KUTISH, J. G. NEILAN, et al. An African swine fever virus ERV1-ALR homologue, 9GL, affects virion maturation and viral growth in macrophages and viral virulence in swine. J. Virol. 2000; 74, 1275-85.

[11] A. S. MALOGOLOVKIN, G. BURMAKINA, I. TITOV, A. SEREDA, A. G. E. BARYSHNIKOVA, D. KOLBASOV. Comparative analysis of African Swine Fever Virus Genotypes and Serogroups. Emerging Infectious Diseases. 2015, Vol. 21, No. 2, 312-315.

[12] R. E. MONTGOMERY. A form of swine fever occurring in British East Africa (Kenya) colony. J. Comp. Pathol. 1921, 34: 159-191, 243-262.

[13] OIE WAHID. World Animal Health Information database (WAHID) interface. htt // wwww.oie.int / wahis / php page = home.2014 public

[14] W. PLOWRIGHT, G. R. THOMSON, J. A. NESER, African swine fever. In: COETZER, J. A. W., THOMSON, G. R., TUSTIN, R. C. Infectious Diseases of livestock with special references to southern Africa. Oxford, Oxford University Press, 1994, vol.1, 568-599.

[15] J. V. M. SANCHEZ. Early detection and emergency plans for ASF. OIE Conf., 2010, 149-158.

[16] D. H. SCHLAFER, J. W. McVICAR, C. A. MEBUS. African swine fever in convalescent sows: Subsequent pregnancy and the effect of colostral antibody on challenge inoculation of their pigs. Am. J. Vet. Res., 1984, 45, 1361-1366.

[17] G. R. THOMSON. The epidemiology of African swine fever: The role of free-living hosts in Africa. Onderstepoort J. Vet. Res., 1985, 52, 201-209.

[18] Veterinary Services Department (DSV), Ministry of Livestock and Water, Chad. Mission report on compensation for pig farmers, 201, 6p. 